\title{
Between the Bairro and the Nation: Performative Identities of Afro-Lusitan Rap Music in Lisbon
}

\section{DARIO RANOCCHIARI}

\section{First Contact}

In 2003, acting on the advice of an Afro-Lusitan activist I had contacted to speak about immigrant children, I bought the very first album released by MC Chullage in a Fnac shop. Rapresálias (Sangue Lágrimas Suor) - Rap-risals (Blood Tears Sweat) ${ }^{1}$ was placed in the 'hip-hop national' section beside a dozen or so other albums and compilations, all distributed by major record companies. I listened to the CD walking through the city centre and to me it seemed rather boring. I did not understand much of the lyrics (the bulk of them being in the Portuguese slang spoken in the poorer immigrant bairros, with a few in Capoverdian creole) and, from a musical point of view, I was completely unimpressed. To me, it appeared to be a globalized music, without either any local Portuguese or African traits. I was not able to identify samples taken from musical genres beyond the usual ones: western classical, rhythm 'n blues, soul, a bit of rock.

Despite this, when I discovered several days later that Chullage was going to perform in a discotheque in Bairro Alto, ${ }^{2}$ I went along to see what it was all about. The venue did not have any specific hip-hop associations. Every night, it would host a concert, play, or video screening. However, that Saturday, well in advance of the appointed hour, young black and white people were gathering, all dressed in hip-hop style. They were speaking quite excitedly about the concert, keeping their distance from the flow of other youth beginning to fill the streets. Some of them admitted to me, during my foray, that this was the first time that they had ventured into the city centre.

The discotheque was half-empty when, at half past eleven, the lights were dimmed and NorthAmerican rap took over. In one corner, some black youths were breakdancing, catching everyone's attention until Chullage came out on stage and was greeted by an ovation. The majority of the audience was comprised of black and white teenagers and a number of black men in their thirties. Many of the teenagers were dressed as b-boys, although a few of the blacks among them were dressed more conventionally. The remaining $40 \%$ of the audience did not differ from the usual discotheque patrons: white foreigners and Portuguese, most of them young, but with a small group of adults between forty and fifty.

The demographic of the audience was quite varied and the concert was unusual, being neither a "hip hop party," nor an event for a gathering of a sub-cultural community, nor simply a popular music concert, like the others I had seen in Lisbon. The difference lay in the relationship created between the rapper and the two principal segments of the audience: the b-boys and the "ordinary" blacks on the one hand and the Bairro Alto people on the other. Members of the former group danced or nodded in time to the music, and many of them, knowing both the lyrics and the songs, sang along. The latter group stood quietly, distant

\footnotetext{
${ }^{1}$ Rapresálias. Sangue Lágrimas Suor CD (Lisbon: Edel Music Portugal, 2001).

${ }^{2} \mathrm{~A}$ city centre suburb which in recent decades, has become known as the heart of the city's night life.
} 
from the show in which the others had become an integral part. This division of the audience became all the more apparent, when, after a brief forty minutes into the concert, Chullage started a freestyle battle. ${ }^{3}$ Those who were in the hip hop group gathered in front of the stage, yelling derisions or cheering every time the MC on duty named a bairro (Arrentela, Cova da Moura, Estrela da África, Miratejo, Miraflores, etc.). Those from the Bairro Alto (myself included) remained detached.

The concert made a greater impression on me than the CD. Above all, the quality of Chullage's performance and those of the other MCs caught my attention, as did the high level of participation of immigrant youths in the event. I contacted Chullage, who invited me to talk with him in the Arrentela bairro, the location of Khapaz, an organization he had co-founded that promotes social activities to "get the young boys off the streets."

Arrentela is located on the other side of river Tagus in Lisbon, on the Margem Sul (south bank), which is the "B side" of the Portuguese capital. To travel from the city centre to the bairro, you have to take buses and a boat, a journey that takes an hour and a half and, in 2003 , cost $€ 3$. Relatively speaking, this is a short and straightforward trip when compared with the time it takes and the complicated connections involved in getting to the other so-called bairros sociais of the metropolitan area. Most of the barrios are close to the city centre, yet they are removed from the 'heart' of the city, as much psychologically as physically, because of the absence of certain services (public transport not the least of them).

When I arrived at the Khapaz for the first time, a workshop was in progress dedicated to education using hip-hop. The subjects covered included Malcolm X, a recent spate of murders in which the victims were youths of African origin, scratching techniques, and the challenge of writing rap lyrics based on everyday experiences. Chullage, naturally, was among the tutors standing in front of some thirty five very young teenagers from Arrentela and other bairros more or less nearby.

Although I was slow to catch on to this, purchasing a Chullage CD in the Lisbon outlet of an international chain of stores, attending Chullage's concert in a Bairro Alto discotheque, and participating in 'education using hip-hop' at the Khapaz association, represented three different but interlinked levels of engagement with the music-identity of African immigrant children who had chosen hip-hop as a reference culture in their diaspora experience. The most local level was to be found at the Khapaz association, where I was dealing with the Arrentela youth community, which featured mostly, though not exclusively, descendants of Africans. The concert brought me into contact with the Lisbon and national "hip hop community," a second level. Finally, at the third and broadest level, when buying the CD, I encountered social groupings on a national scale.

This perspective changed my point of view about that first concert and the other musical and contextual aspects of my investigation. Before attending the concert, I had already made prejudicial judgments as to its "authenticity" as a hip-hop party. As a result, the freestyles, which I considered rather more "authentic" than what had preceded it, surprised me. Moreover, at the concert, I focussed on observing the $b$-boys and ignored the other section of the audience-the distanced group to which I in fact belonged. I was considering my group external to the event, assuming its other members were unaware of what was "really" happening around the stage. Authenticity, however is a slippery category. If there was something meaningful about my observations about the different audience groupings, one "internal" and the other "external" to the hip hop scene, it did not reside in the greater authenticity of one over the other, but in the

\footnotetext{
${ }^{3}$ When two or more rappers challenge each other in an improvised linguistic battle.

${ }^{4}$ Chullage, interview with the author, 2003/12/14.
} 
fact that Chullage had given a concert, on a Saturday night in the Bairro Alto, putting the hip hop of children of the African diaspora on a principal stage at the vanguard of Portuguese culture.

\section{Globalization of Rap in Portugal}

Where does the hip hop scene in Portugal come from and how is it structured, especially in Lisbon? Why do I consider it important to be able to understand the identification processes of the children of African immigrants? As Andy Bennett has observed, the local context of use and production of popular music should not be seen as a coherent whole, but as a collection of interrelated discourses. ${ }^{5}$ From this perspective, music that might be produced in one country is accepted in another according to local musical sensibilities-sensibilities that, in all probability, were developed through the integration of other music of outside origin. Bennett's observation is very useful when it comes to understanding how it is possible to relate specific identities to elements that seem, at first sight, so far removed from the local context. In the case of hip hop, commercialization has facilitated passage from local phenomenon to an accessible, identifiable, mediatized and therefore, generally well-accepted phenomenon. Music like rap has reached many parts of the world as a result of globalization. Where it becomes entrenched, the models and symbols of American hip hop combine with local parlance and musical languages, creating a new means of communication.

The studies in Global Noise, edited by Tony Mitchell, demonstrate the active and heterogenous role local contexts have played in the globalization of hip hop. ${ }^{6}$ What brings these contexts together though is the ability of hip hop to give voice to convictions about social or ethnical identities that are often polemical, and, in many cases, involve politics or ideologies (e.g. the centri sociali movement in Italy). ${ }^{7}$ In some countries, it is brought into relation with a nationalist cause or an ethnic minority (e.g. Euskadi rap). ${ }^{8}$ But more often it finds resonances in countries which have gone through some kind of cultural diaspora and undergoes an ideological transformation in the process. For example, the symbols of African American identity in hip hop are refigured as symbols of Turk-German identity or, in this case study, Afro-Lusitan identity in Portugal.

The rap explosion in Portugal occurred in a period of radical changes. During the 1990s, Portugal began dealing with its post-colonial multi-cultural population. Demographically, in the second half of the twentieth century, the country had become an intricate cultural lattice. On the one hand, there were returning Portuguese who had left originally to settle in the country's African colonies, while on the other, there were intellectuals and farmers who immigrated illegally, from the Estado Novo of Salazar, to a richer and freer Europe. At the same time, many young Africans, considered by Salazarian law as effectively Portuguese, immigrated to Lisbon to work and study. With the start of the nationalist independent movements and the decolonization process following the 1974 Carnation Revolution, many colonials chose their Portuguese nationality and returned to Europe (the so-called retornados), while the Portuguese diaspora continued in France, Holland, Germany, and the United Kingdom. Complicating the cultural geography further was the transformation of Portugal from a country of emigration to one that received

\footnotetext{
${ }^{5}$ Andy Bennett, Popular Music and Youth Culture: Music, Identity and Place (Houndmills: MacMillan, 2000).

${ }^{6}$ Tony Mitchell, Global Noise: Rap and Hip Hop outside the USA (Middletown: Wesleyan University Press).

${ }^{7}$ Tony Mitchell, "Fightin' da Faida”, in Global Noise: Rap and Hip Hop outside the USA, ed. Tony Mitchell (Middletown: Wesleyan University Press), 194-221.

${ }^{8}$ Jacqueline Urla, "We Are All Malcolm X!", in Global Noise: Rap and Hip Hop outside the USA, ed. Tony Mitchell (Middletown: Wesleyan University Press), 171-193.
} 
migratory flows, not only stemming from ex-colonies but also from China, Brazil and Eastern Europe, a result of Portugal's entrance into the European Union in the middle of the 1980s.

In this context, the "hip hop nacional" (as it is classified on the shelves in record stores) or tuga rap (from the country's name "Portugal") was born. At the beginning of the 1990s, the only people who listened to rap were children of the cultural African diaspora or Portuguese immigrants, resident mostly in the bairros sociais (cheap residential quarters) or in the vast bairros de lata (shanty towns) in Lisbon's suburbs. What they listened to mostly were recordings of American rap passed on by friends or relatives returning from work in other European countries where this musical genre was not only a globalized phenomenon but also was beginning to root itself in the local reality, progressively assuming meanings tied to the cultural diasporas. The English language, used by the first Portuguese MCs in imitation of the American model, was soon abandoned in favor of Capoverdian creole and Portuguese, often mixed in hybrid linguistic forms that also drew on câlao (street slang), and English.

A radio program called Submarine, playing on the name of the producer and invoking the underground nature of the music that it aired, brought the rap music of the bairros its first commercial triumph, attracting attention to a compilation called Rapublica. ${ }^{9}$ It was a huge success that made the national hip hop movement visible for the first time and suggested its commercial potential. From that moment on, tuga rap attracted widespread media attention. The themes that were addressed in the songs, the type of producers and audiences, and the styles within the genre began to change. In an important development, many young people from the middle class began to take interest in hip hop, listen to and produce rap music themselves, and assume a hegemonic position in the determination of the market.

To the active underground scene was added a more commercial one, less hard core, less ethnicized and not localized in the bairros. Whether the rappers were immigrants or were native to Portugal, hip hop had rapidly completed a cross-over process, able to attract - depending on the appeal and the sonority of the various groups-a vast audience, members of which might not necessarily belong to the hip hop subculture.

The enlarging of audiences did not result in a change in the meanings associated with this musical genre, either in the discourse of the media or its fans. Rap continued to be regarded as music of and for young people of African origins. At the same time, the capacity of hip hop to fill in some symbolic holes in the new social universe did not escape institutions - governmental agencies, NGOs, mass media. These institutions -were beginning to deal with the new Portuguese multiculturalism, emerging between 1994 and 1995, a kind of actualization of the borders of the national culture.

Anthropologist Teresa Fradique, who has produced the most elaborate Portugese analysis of tuga hip hop, explains that if the fado has the job of representing the national culture in an abstract and collective way, hip hop has the job of representing what this culture has that is different. The concept that rap appeals only to children of immigrants, mostly African, who supposedly live in the Lisbon suburbs, helps to identify it as "another Portuguese cultural language, or better yet the cultural language of the Other." 10

A politically correct view of rap, which characterized it as an attack on racism and the social injustices resulting from the demographic changes of contemporary Portuguese society, allowed the genre to become one of the best means through which cultural differences have been made manifest. This process contributed to rationalize (or tame) the phenomenon, because it was the same politically correct rappers

\footnotetext{
${ }^{9}$ CD compilation, Rapública (Lisbon: Sony Music Portugal, 1994).

${ }^{10}$ Teresa Fradique, Fixar o movimento: representações da música rap em Portugal (Lisbon: Dom Quijote), 20.
} 
who, accepting the position given to them by the Portuguese institutions, put themselves at "the disposal of a policy that embraces the ethnical minorities and simultaneously recognises their marginalization." 11

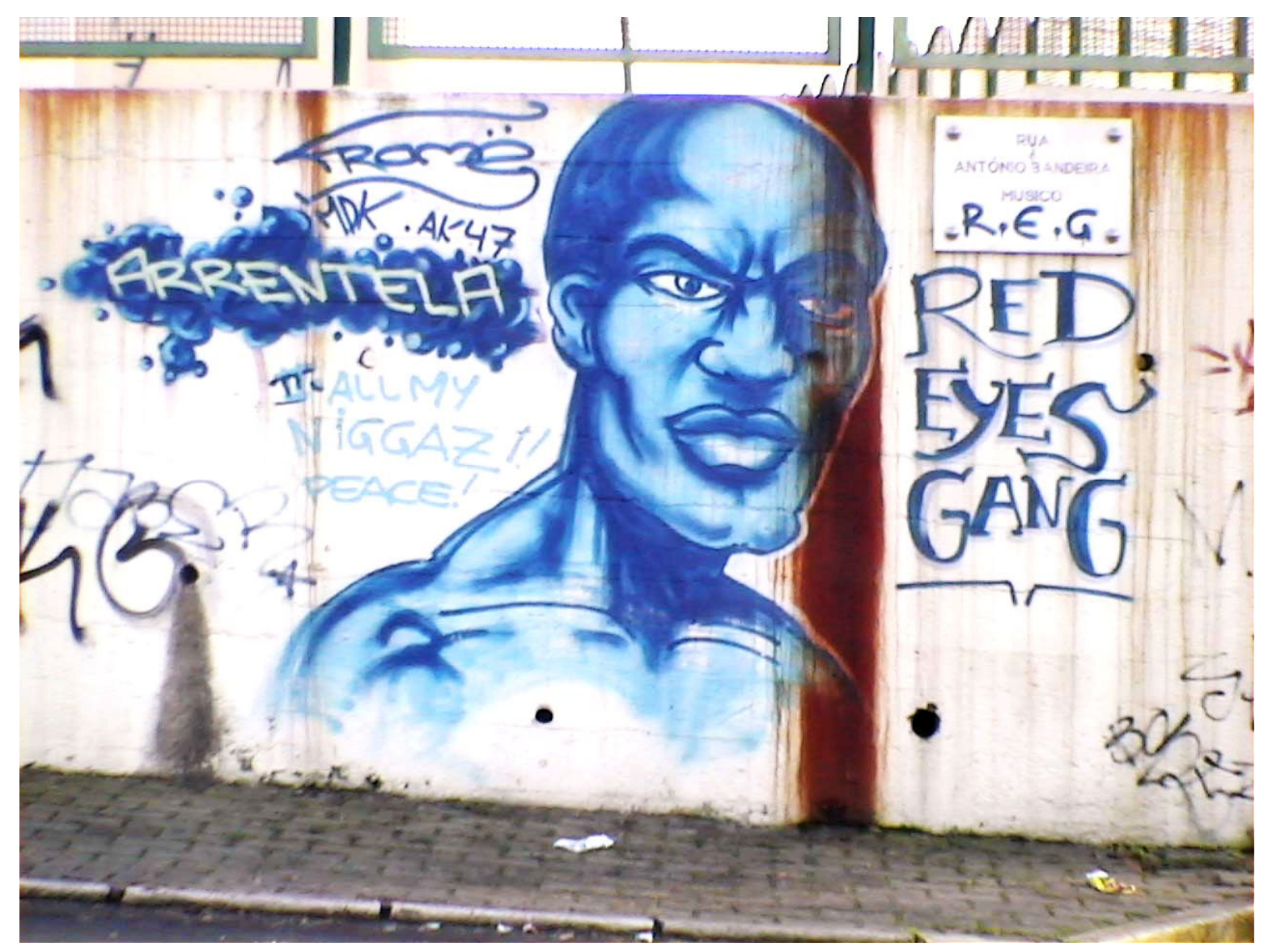

Figure 1. A graffiti in the Khapaz association's bairro social.

\section{Chullage between the Bairro and the Nation}

It was in this context that Chullage became active in the hip hop community. Born of Capoverdian parents in a shantytown toward the end of the 1970s, his father was a builder and his mother a maid. Despite these circumstances, Chullage managed to finish school and enter university in the faculty of sociology. He began to rap at the age of fifteen, and in 2001, thanks to the support of a French producer, a son of Portuguese immigrants who came back to Lisbon, he published Rapresalias. Unexpectedly, it was a success. Chullage became one of the most influential figures on the national hip hop scene, giving voices to his most politicized and ethnicized views. Chullage's celebrity had repercussions beyond influencing the internal shape of the hip hop movement. The mass media made him one of the symbols of the tuga rap and reinforced the connection of this musical genre with the world of suburbia and people of African origins.

${ }^{11}$ Ibid., 132. 
Chullage understood very clearly the problem of his celebrity: that his rap was being used in the mass media context as a useful symbolic product to render harmless the otherness of the children of immigrants. He was highly conscious of the critical juncture at which which tuga hip hop had arrived. In his own words, there was a war between "hip hop branqueado" (which means "whitened" and references those white Portuguese who hold on to economic and symbolic power) and "hip hop consciente" (which means conscious of its black origins and underground roots from the suburbs of Portugal). His approach was neither to assume the position of a mainstream rapper nor refuse success, removing himself from the national stage for the sake of preserving an underground essence. It is a position strategically ambiguous that is, at the same time, both his greatest strength and weakness. On the one hand, it has allowed him to reach a relatively vast and varied audience, both ethnically and socially, and on the other hand, it appears to clash with his own black radical ideology, which emerges in his songs and interviews.

When I say that this position is strategic, I do not wish to say that Chullage has a special capacity to resist the pressures of the record industry and the way he is portrayed in the national mass media. On the contrary, he reveals the difficulty of facing and maintaining a position diametrically opposed to the hegemonic logic of the marketplace and of symbolic portrayals by means of music. To split MCs into those who work with the system and those who oppose it, is an ideologically valid operation within the internal debates of the hip hop movement and the discursive rhetoric of artists in their lyrics. But those who invoke it uncritically in their analyses make invisible the processes of continuous bargaining that occur between artists, audiences, the marketplace, and the mass media.

When I met him in 2003, I rapidly modified my research project to centre the fieldwork on him and the Khapaz association of young people that he founded in the bairro where he lives. As a successful rapper and, at the same time, as a boy living and doing social work in a bairro social, Chullage seemed an appropriate candidate for analyzing and understanding the relations that arise in the passage from the identity of young African immigrants in the context of the bairro to national identity and the representation of a Afro-Lusitan identity. It is a journey from the bairro to the nation, and vice versa.

In this regard, I would like to note that the term Afro-Lusitan is not commonly used in Portugal. Generally, the Portuguese refer to African immigrants and their children as negros portugueses (Portuguese black people) or more precisely by referring to their original nationality: luso-caboverdianos, lusomozambicanos, etc. I chose to use the term Afro-Lusitan to identify a relatively new kind of identity configuration in which one's origin in a specific African country does not matter as much as the shared experience of being children of immigrants in Portugal.

To rap, for Chullage, is a political act. It means issuing a social critique of a country that he considers "racist and hypocritical." 12 This is an idea that would be superficial without action in 'real life,' so dear to the hip hop ethic. The foundation of the Khapaz association (which translates roughly as "Capable"), and Chullage's choice of working there every day must be seen in this perspective, and it is not an exaggeration to say that the work for the bairro through the Khapaz association is a fundamental contact point between Chullage's music and life.

\footnotetext{
${ }^{12}$ Interview given to Fornal Ruptura (2002).
} 


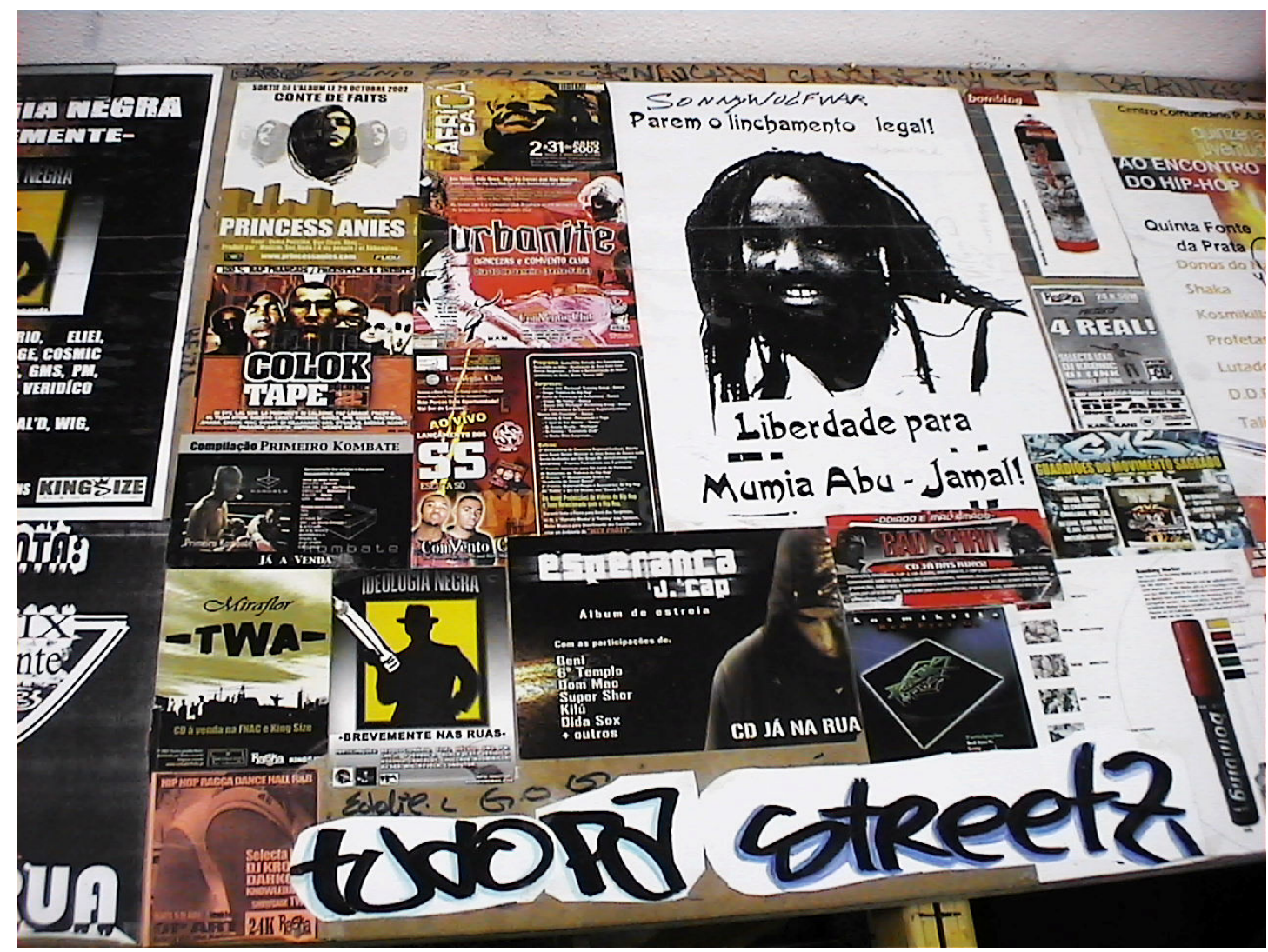

Figure 2. Hip hop flyers decorating the table of the Khapaz rehearsal room.

The Khapaz association, founded significantly in the same year of the publication of Rapresalias, is well rooted in the neighbourhood where it is located, and has the important function of serving as a meeting place for kids in the quarter. During my fieldwork, young people between the ages of fifteen to thirty years old gravitated to it. Of these, the regular attendees numbered about thirty, most belonging to the Red Eyes Gang (Chullages's hip hop crew). The Khapaz is therefore a privileged space in which to observe how hip hop and rap music are able to affect the cultural identity of young people in the performative space of a bairro social.

The Khapaz association has essentially three main objectives:

1) to act as a safe place in which kids (not necessarily of African origin) can socialize;

2) to valorize the common cultural roots of Africans in Portugal, opposing the loss of consciousness of origins (its personnel achieve this in large part through AfroteKa and Afrodok, a library and an archive devoted to material on the subject of diaspora), and

3) to provide recording facilities for the production of hip hop and, particularly, rap music.

Placing a priority on hip hop was a fundamental to attracting young people. The recording room has worked as a centre for the diffusion of hip hop culture in the quarters, attracting young immigrants' attention to the music. There are four principal elements that appeal: the attention of the American media to the rap phenomenon through globalization; the ideological strength demonstrated in the diffusion of pro-African messages; the practical possibility of rapping every day; and the revelation, through the exemplary experience of Chullage and other members of his crew, of the chance to rap within a national 
market without having to leave the bairro. Or, putting it differently, Hip Hop offers the possibility of introducing the bairro to a new social context.

What interests me the most is this last point. In the eyes of the young people, Chullage is the living example of the possibility of rapping not only to the ghetto but from the ghetto. The fact that he has arrived at the top without leaving the suburbs behind-continuing his work for the bairro, to sing for the bairro, to tell his story in the bairro - not only builds an ideal bridge between individual and group identity, but also, on a wider scale, forging Afro-Lusitan society. Every time Chullage has appeared in the national media (newspapers, magazines and TV), he has always brought with him the image of his neighbourhood and of the Khapaz association. He never leaves to give interviews, always expecting the journalists to come to the bairro to interview him. As a result, the kids of the bairro appear not only on the covers of Chullage's albums, but also in every newspaper or magazine article about him. Participating in the construction of Chullage's public figure means that the young people participate in a larger phenomenon.

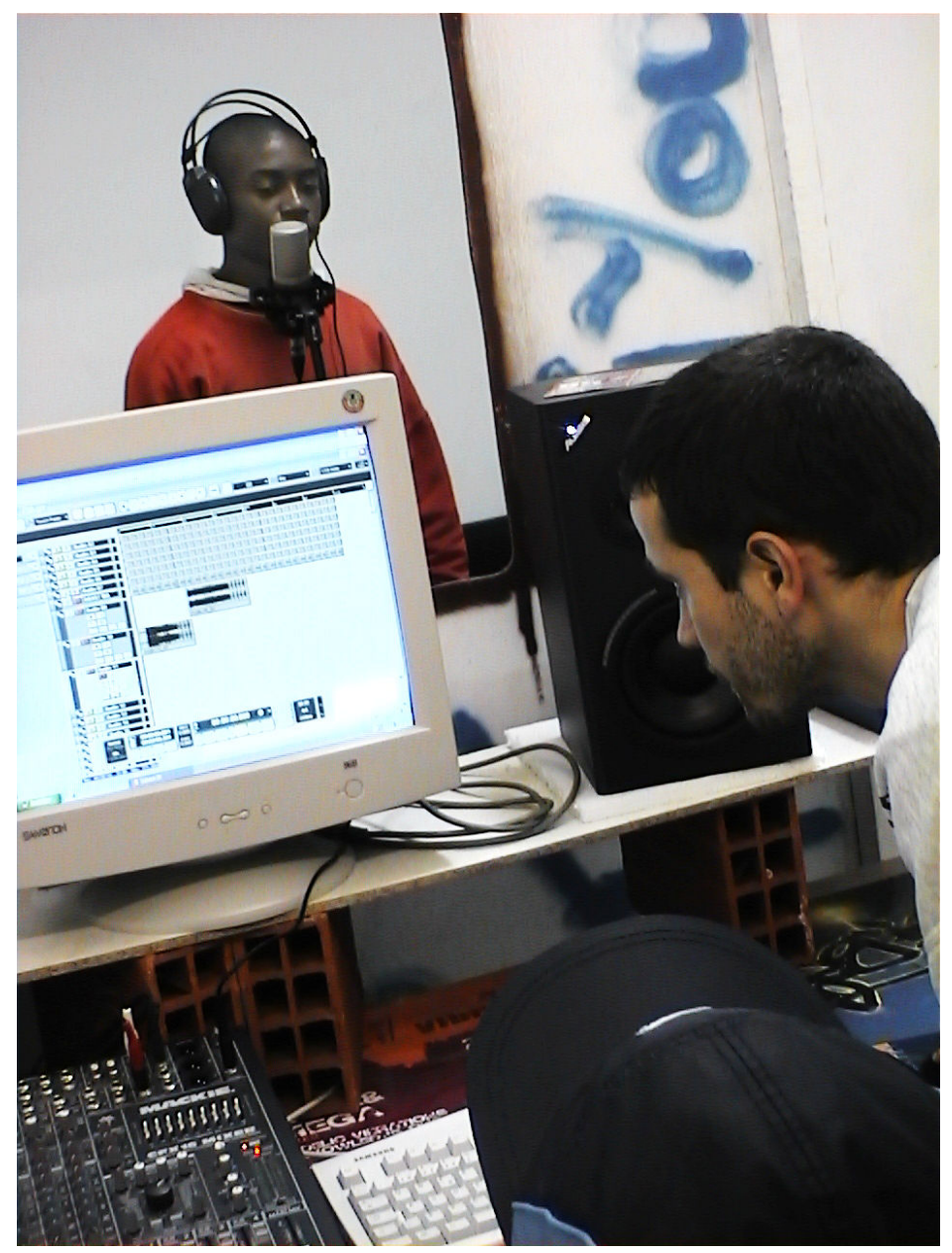

Figure 3. A young boy rapping in the Khapaz association. 


\section{Rhetorical strategies}

But how does Chullage achieve this fine balance? The answer lies in part with the themes and rhetorical strategies Cullage utilizes in his lyrics, rhythms, and beats. Space does not permit a more extensive discussion of the rhetorical strategies, suffice it to say that they are aimed at constructing parallels between everyday life in the bairros and American ghettos, establishing a line of continuity between past and present, between slavery and the present exploitation of immigrants and their children. To achieve this, Chullage emphasizes the idea of reconstructing African roots and deploys binary oppositions: north and south, white and black, niggaz (niggers) and tugas (Portuguese).

Regarding the beats, it is worth noting that samples from African music are not utilized, nor are those of the local Portuguese music. This may seem to contradict the mandate of an MC who stresses the importance of African lineage in the national image of tuga hip hop. In my conversation with Chullage and with the Khapaz young people, every single time I touched on the theme, I got vague answers, revealing that they had never thought about the theme. Very simply, they did not see any contradiction.

The sound of tuga rap and its praxis (clothing, stage settings, daily behaviour, drink preferences, and, in some cases drug choices), asserts cultural ties to a global, modern, and urban African identity, even while it denies any direct reference to what is ethnic. Hip hop's appeal has to do precisely with the connection that it established with a worldwide diasporic practice based in an urban African-American experience, which comes to be read as a mythic narrative. To appropriate hip hop means to absorb this symbolic universe, encompassing musical practices, whether ethnic or local, which are available in a display of possible options.

From this viewpoint, the exclusion of local African and Portuguese music represents an oppositional perspective; it suggests a difference in the way that immigrants and their children perceive cultural origins. There is, in fact, a difference between being an immigrant and the son of an immigrant, and it is this difference that hip hop provides a means of articulating, becoming, in the process, a filter for local cultural differences. African music such as morna, coladeira and kizomba is the music of the fathers. Rap is (one of) the musics of the new generation.

It is obvious then that tuga hip hop in general, and the pro-African and political rap of Chullage in particular, speaks to the children of immigrants in the bairro. It does not invoke the Africa where their parents were born, but a mythical Africa that lies behind every diaspora. Therefore, to build and maintain ties to their cultural roots-so important to the creation of diasporic identity-the children of the African immigrants in Portugal (who have chosen hip hop culture) look at Africa through the mirror of North American ghettos.

According to Chullage, the affirmation of the blackness of hip hop serves as an antidote to the subordination of Africans in Portugal. It is the affirmation of a politically "conscious" rap in opposition to an "unconscious" or unengaged rap. And the "conscious" rap is furthermost represented by Chullage as black rap.

There are many good examples, but a particularly effective one is the song, 16 Barras (Bar Code), recorded on Chullage's second album Rapensar: Pasado Presente Futuro (Rap-think: Past Present Future). From the sound point of view, the song contains the characteristic elements of rap (the voice singing with the typical rapping flow, the chords and the synthesizer sounds as rhythmic support, etc.). With regards to the musical structure, it is quite basic, though not at all rigid. It begins with an introduction of $184 / 4$ bars, 
which is followed by a 2-bars pause acting as a bridge to the second verse. The bridge is comprised of 8 bars, and it is followed by a 4-bar pause that serves as a prelude to a verse of 21 bars. The phrase structure proceeds in this variable way until the end. Such a free structure suggests that it may be the lyrics that are the elements of primary interest, as is the case in the majority of Chullage's songs.

I quote some particularly meaningful lines the idea of "conscious" rap being black:

[. . .] todo o euforismo k o hip hop vive é apenas periódiko/ mas já tem niegas de kalças po chao, num ângulo rekto por um chekkke módiko/ komo Jazz e Rock oportunistas apoderam-se do hip hop num roubo metódiko/ pa daki a uns anos ser lembrado komo um costume nórdiko/ [...]/ por mais lixivia $\mathrm{k}$ a kkkomunicaçao/ passé no hip hop, eu permaneço a nódoa/ por mais $\mathrm{k}$ tente brankkkear esta arte, eu venho sujo e inkomodo-a/ [ . . ]

[...] the euphoria that hip hop lives right now is only temporary/ there are already niggas with their pants low/ bending at ninety degrees for a miserable cheek/ like it happened for Jazz and rock, the opportunists take control of hip hop with a methodical theft/ so that it may be remembered in a few years as a Nordic custom/ [ . . ] /no matter how much bleach the media places on hip hop/ I remain a stain/ no matter how much they may try to whiten this art, I'm still dirty and I cause discomfort [to the media]. ${ }^{13}$

Audio accessible at: www.youtube.com/watch?v=U0EbyytLfmI

Whitened hip hop is therefore a commercial, acritical, unconscious music, while "conscious" rap is a "stubborn stain" and "dirty." It is "black."

But are the bairros really only comprised of black immigrants and their children? What about the children of Portuguese immigrants who share the same life in the neighbourhood and in the Khpapaz association: are they tugas or niggaz? And what about the black rappers who are part of commercial crews? What about DJ Sas, who arranges Chullage's beats and is his partner in the Khapaz association, the white son of Portuguese parents who immigrated to France and then returned to Lisbon? In the Khapaz association, there is no strict distinction drawn between black and white people, despite the continuous references to the African ideologies I have discussed.

Certainly, it is not only the sons and daughters of African immigrants who listen to Chullage. This fact alone should suggest to us that the blackness valorized in his songs is not to be taken literally, but is instead a function of political ideology. The advantage of using hip hop instead of African music to signify his own blackness points precisely to the ambiguities surrounding the meaning of "black." This ambiguity allows a wide range of immigrant children in Portugal to identify with hip hop music, whatever their cultural or racial backgrounds may be. Tjeu construct for themselves a performative identity as different from that of their parents as from Portuguese of the same age. I call this identity configuration AfroLusitan.

13 "16 Barras" from the book of the double CD Rapensar: Pasado, Presente, Futuro (Lisbon: Lisafonia, 2004). Translation by author. 


\section{Conclusions}

To conclude, tuga hip hop is not linked solely with the socio-cultural realities of the bairros, or with its Afro-Lusitan components. Despite this, it is particularly well suited for creating and performing a new specifically Afro-Lusitan identity in everyday life.

Chullage's decision to remain suspended between the mainstream and the underground allows him to mediate between two points of view: on the one hand, the conviction that hip hop should provide conscious and real support for the construction of an Afro-Lusitan identity for young people in the bairros; on the other, the belief that the music grants the Afro-Lusitan community space in the Portuguese nation's

social background. To make this possible, Chullage is fighting the dichotimizing tendencies of the hip hop world, which insists on the opposition of an active and countercultural rap, the expression of its black origins, and a commercial and branqueado rap-a slave to the hegemonic culture. This resistance also defines the Afro-Lusitan experience within the large context of Portugese society. 